\title{
RESEARCH ON THE FINANCIAL TRANSPARENCY INTO THE HEALTH PUBLIC SYSTEM IN ROMANIA. CASE OF HOSPITALS SUBORDINATED TO THE HEALTH MINISTRY
}

\author{
Aurelia Ştefänescu ${ }^{1}$ \\ Eugeniu Tुurlea ${ }^{2}$
}

\begin{abstract}
The complexity of the public hospital activity, generated by the high resource consumption, high number of actors involved into the medical act, technological innovation, heterogenous healthcare services offered, typology of hospitals, diversity of financing sources and suppliers of financial resources as potential patients, demands a high degree of financial transparency. In this context, by the qualitative research performed, we identify the degree of financial transparency at the level of public hospitals subordinated to the Health Ministry from Romania. This study takes into consideration a synthesis of the ideas published on this theme into the professional literature, as well as of the regulations issued by the national and international accounting regulators, by accounting entities. The results of the research pointed out that the financial transparency promoted by hospitals through the agency of official web sites is low. For most of hospitals the financial transparency is limited to the publication of revenue and expenditure budget. Only three hospitals display the completed financial statements and a reduced number of hospitals limits financial transparency at the individual level of the budgetary execution account, ballance sheet and patrimony outcome account. Also, we observe that in geographical terms, there are no significant differences regarding the hospital financial transparency. In respect of the temporal view, the published financial information is heterogenous both at individual level and global level, fact diminishing the comparison in time and space. The difficulty of investigating financial transparency of hospitals is increased by the difficulty of identifying the official sites of hospitals when lacking a database at the level of Health Ministry.
\end{abstract}

Keywords: transparency, financial information, public hospital, stakeholders, Romania

JEL Codes: M41, I100, H83

\section{Introduction}

In the context of a tourmented economic environment, with negative impact upon the population's incomes, of the financial resources asigned to hospitals, but also the hospital service quality, there is increased the disbelief of the public as a supplier of financial resources and a beneficiary of services, as well as of other stakeholders regarding liquidity, solvability of the entityand sustainability of delivering the hospital services. In this respect, the performed studies introduced and validated an innovative approach of performance into the public hospitals from Romania, respectively performance by coercion according to which, the diminution of financial

\footnotetext{
${ }^{1}$ The Bucharest Academy of Economic Studies, Bucharest, Romania, e-mail: stefanescu.aura@gmail.com

${ }^{2}$ The Bucharest Academy of Economic Studies, Bucharest, Romania, e-mail: eturlea@yahoo.com
} 
resources asigned to hospitals affected their sustainability given the fact that the extra budgetary revenues that have complementary financing role and survival assurance role were either absent or deficient (Ştefănescu et al, 2013). From this view, the performed study has as objective identifying the degree of financial transparency within the public hospitals subordinated to the Health Ministry. The choice of this type of hospitals is argued by the subordination relationship, the integration of all financing manners and the destination of the financing asigned from the state budget through the agency of the Health ministry, which should generate a plus of financial transparency. The destinations of financing received by these hospitals through the agency of the Health Ministry are the following: implementation of national programmes of public health; procurement of medical equipment and other facilities independent from the capital expenses, according to regulations; investment related to the construction of new hospitals, including for the completion of those being executed; expertise, transformation and entrenchment of the buildings seriously damaged by earthquakes and other force majeure cases; modernization, transformation and extension of the existing constructions, as well as execution of heavy repairs; activities specific to ministries and institutions with personal sanitary network, approved by Government decision; teaching and fundamental research activities; financing of activities within sports medicine, forensic medicine, family planning, TBC, HIV/AIDS programmes, personnel rights for residents; assurance of expenses for the Receiving Emergency Units and Departments of Receiving Emergencies (Law no. 95/ 2006 with further modifications and completions).

\section{Research methodology}

The research is two-dimensional, respectively interpretative and qualitative. Using an interpretative type research, the paper presents from general to particular, the conceptual approaches regarding the financial transparency in the public sector. In this regard, we took into consideration the ideas published in the literature, but also the investigation and interpretation of regulations in this field, developed by national and international regulators. This undertaking was completed by the qualitative research on the grounds of which there were investigated the official sites of the public hospitals subordinated to the Health Ministry from Romania to identify the extent to which these entities publish financial information related to the financial reporting.

\section{Concept approaches on the financial transpanrency into the public sector}

In general terms, transparency is a manner of action or a principle of certain leaders to publicly make their entire activity known permanently (http://dexonline.ro/).

In another view, transparency is defined as an open informational flow (Piotrowski, 2007). Reported to the public speech for good governance, Ball (2009) asserts that transparency prevails over morality. Transparency is correlated with the moral values due to the fact that it allows the citizens to make sure of the quality of public services and it stimulates the state to satisfy the citizens (Holzner and Holzner, 2006).

From financial point of view, the results of the research undertaken by KPMG (2007) at the level of various entities (ministries, local collectivity, banks, etc) showed different connotations of the phrase financial transparency. Thus, $24 \%$ of the respondents consider financial transparency an instrument of external communication, and $33 \%$ of them associate it with the financial statements. For $15 \%$ of the respondents financial transparency idicates the facility to read documents whereas, $13 \%$ associates transparency with the access to internal information. Starting with the indicators of financial transparency, respectively accessibility, completeness, legibility and regularity of financial information, the results of the research emphasized that the highest importance is assigned to them by the public sector entities. 
Carrin at al (2006) approaches transparency in terms of health insurance typology. In this respect, the authors appraise the compulsory health insurance system is characterized by a high degree of financial transparency due to the fact that contributors pay directly and benefit of preset medical services. In another view, Ayoubi(2009) considers that the improvement of transparency in terms of medical care services and the related costs at the level of health care in Switzerland have been made by introducing the diagnosis group system (SwissDRG, 2012). Doumbouya (2008) asserts that improving transparency at the level of hospital management, constant financing and sustaining the development by the state and involved partners, could assure the constant and efficient functioning of hospitals. Having as premise the operational objectives for a new governing within health care, Sout (2010) militates for consolidation of transparency as the attribute of health democracy consolidation.

From another view, the consolidation of financial transparency is achieved by the management control (Langilier, 2003). The reasons for that are dual: the management control is often the interface of a good financial communication, respectively a global system of internal information at the level of local collectivities which allow centralization, summarizing, exploitation of a data assembly.

Promotion, consolidation and improvement of financial transparency, of financial reporting quality and responsibility into the public system represent a permanent objective of the international entities od accounting regulation. Thus, the International Public Sector Accounting Standards Board (IPSASB) by issuing the International Public Sector Accounting Standards (IPSAS) contributes to the delivery of more relevant information for financial management and decisional process within the public sector, in the context of heterogeneousness of political, cultural, administrative and jurisdictional systems. In this respect, IPSASB encourages governments to harmonize the national regulations with the International Public Sector Accounting Standards (IPSAS). Thus, IPSASB help the receivers of public services and suppliers of financial resources by tracing the coordinates of financial reporting in general terms. According to IPSAS 1 Presentation of financial Statements, the objectives of general financial statements consist in offering information on the financial situation, financial performance and treasury flows of an entity, useful for a wide scale of users in adopting and assessing decisions concerning the asignment of resources. The achievement of these objectives is grounded upon the complete general financial statements including the following components: a statement of the financial situation; a statement of the financial performance; a statement of the modifications within the structure of assets / capitals; a statement of the treasury flows; a comparison of the budgetary values and the real ones, either as an additional individual financial situation, or as a column of the budget into the financial statements, in case the entity publicly discloses its budget; and the notes comprising a summary of the significant accounting policies and other explaining notes.

In Romania the issue of financial reporting within the public sector is regulated by Order of the Public Finance Minister no. 1917/2005 for the approval of Methodological regulations regarding the accounting organization and management of public entities, accounts planning for the public institutions and the instructions to apply it. The modifications brought to this regulation by Order of the Public Finance Minister no. 2021/2013 considered the achievement of the objective of drawing up and reporting the analytical assessment ballance sheet by all public entities to the Public Finance Ministry. In this respect, the modifications were limited only to the technical aspects related to accounting, regarding the structure and functioning of accounts, promotion of cash accounting at the level of the account plan, being ignored the aspects regarding financial reporting. Therefore, the the coordinates concerning the financial reporting remain valid, being traced by the OMFP 1917/2005 and the methodological regulations on the quarterly and annually drawing up and submission of the financial statements of public institutions, periodically published by the Public 
Finance Ministry. In this respect, the traced coordinates are two-dimensional. The first dimension is circumscribed to the components of the quarterly and annually financial statements, respectively, the ballance sheet, the account of patrimony outcome, the treasury flow situation, the situation of modifications within the structure of assets / debts, the annexes to the financial statements, the budgetary execution account. In this view, the financial statement is the official document of presenting the patrimony situation belonging into the state administration and the territorialadministrative units and of the execution of revenue and expenditure budget and they have as declared objective to display an accurate image of assets, debts, financial statement (net assets / net patrimony / own capital), as well as the financial performance and the patrimony outcome. The second dimension takes into account the transparency of financial reporting which is partial, compulsory and limited at the level of public sector entities, as it follows: the public institutions have to submit to the state treasury units where they have open account, the statement of the treasury flows to obtain visa regarding the accuracy of cash payments, balances of cash in bank, if the case, in order to comply with the data into the public institution accounting with those of the state treasury units accounting; the public institutions whose managers act as second or third credit managers, submit a copy of the quarterly and annually financial statements to the first credit manager, at the deadlines set by the latter one; the representaitves of the public authorities, ministries and other entities of the the central public administration and autonomous institutions have the obligation to submit the centralized financial statements to the Public Finance Ministry; the first credit managers of local budgets have the obligation to submit the financial statements to the General Directorates of county public finance and of Bucharest municipe; the public authorities, ministries the other entities of central and local public administration whose managers act as first credit managers, have the obligation to display the annual financial statements centralized on the personal web site page or, in case of its missing, at the headquarters of public authority/institution, according to Law no. 544/2001 regarding the free access to the public interest information, with further modifications and completions; the annual financial statements centralized on the entire public administration, as well as on each public administration subsector are displayed on the web site of the Public Finace Ministry (Methodological regulations regarding the drawing up and submission of financial statements of public entities on the 12.31.2013). Also, the financial reports related to to the 2013 financial year are submitted at the mentioned institutions both on paper and on electronic support.

The study of the national regulations regarding financial reporting shows that they include two components: an accounting component, limited in terms of transparency approach (OMFP 1917/2005, Methodological regulations regarding the drawing up and submission of public entities financial statements) and a component related to transparency within the public sector (Law no. 544/2001 regarding the free access to the public interest information, with further modifications and completions). According to Law no. 544/2001 regarding the free access to the public interest information, with further modifications and completions, the financial information that the public sector entities must voluntarily communicate consists of financial sources, budget and ballance sheet. In terms of communication manners, these ones are various: display at the entity's headquarters or publication into the Official Monitor of Romania or into mass media means, in personal publications, as well as on the personal web site page; consultation at the headqurters of the authority or public entity within special locations. The comparative analysis of the national regulations in respect of financial reporting shows that the two components are divergent from the published information point of view but convergent in terms of the information communication manners. The limitation of accounting regulations regarding the financial transparency into the public sector is emphasized also by the fact that within their framework, the transparency concept is never mentioned, unlike the IPSAS, where it is mentioned twenty times. 
The study performed at the conceptual level emphasizes the fact that financial transparency reflects the easy access of stakeholders to the internal information of the public sector entities, the degree of achieving the objectives towards the resource suppliers, service beneficiaries and other stakeholders. A major role within the process of assuring and promoting financial transparency into the public sector is taken by the accounting regulating and irregulating entities and by the entities' managing board, too, taking into consideration the manner of financing the entities of this sector and the existance of principal-agent type relationships.

\section{Research on the financial transparency into the public hospitals subordinated to the Health Ministry}

This research takes into consideration the results of the empirical study performed at the level of the central public administration entities from Romania which showed that the extent to which they disseminate complete financial information through the agency of official sites is very low. The information disseminated on the official sites predominantly by entities from the central public administration consists in the revenu and expenditure budget, net monthly salary incomes ans activity reports (Ştefănescu and Țurlea, 2013).

In order to identify the degree of financial transparency at the level of the public hospitals subordinated to the Health Ministry, we turned to the investigation of these entities' sites. In this respect, we took into consideration the financial information circumscribed to the financial reporting, both the current one and the historical one. Annex 1 displays the extent to which the public hospitals subordinated to the Health Ministry promote financial transparency, as well as the typology of financial information.

The research performed at the level of the 71 public hospital subordinated to the Health Ministry (Government of Romania, Decision no. 524/2013) shows a low degree of financial transparency, fact revealing a diminished concern of the hospital managing board, of the ministry as a superior credit manager, but also of the accounting regulation entities. Thus, $8 \%$ of hospitals do not display financial information on the official site, $6 \%$ have a non-operating site and one hospital does not have site (Poiana Mare Lunatic Asylum). Most of the hospital sites (71\%) give iformation regarding the revenue and expenditure budget and out of them only $6 \%$ offer updated information. Also, only 5\% of hospitals (Neurosis Sanatorium Predeal, National Institute for Complementary and Alternative Medicine "Prof. dr. Florin Brătilă-Bucuresti", Balneary and Recovery Sanatorium Techirghiol) assure financial transpanrency through the agency of complete financial statements out of which $3 \%$ display updated information. Among the components of the financial statements individually published on the sites of the investigated hospitals, the account of budgetary execution is published by $12 \%$ of them, the ballance sheet is displayed by $8 \%$, and the patrimony outcome account by $3 \%$ of hospitals. We notice that individually the treasury flow statement, the situation of modifications within the structure of assets/debts, the annexes to the financial statements do not occur on the hospital sites. Complementarily, the hospitals are concerned with the promotion of financial transparency also by other information, such as: $17 \%$ publish the registers of operations generating payment bonds, $4 \%$ present the monthly execution of the revenue and expenditure budget, $4 \%$, reports regarding the monthly consumption of medicines, $5 \%$ publish the expenses for externalized medical services, only one hospital displays the daily payments performed and two hospitals publish the trial ballance. 33\% of hospital sites present the tariffs of analyses and medical investigations offered, but they are also limited in respect of relevance for the potential patients because there is not specified their validity period. 


\section{Conclusions}

The performed research shows that in respect of concept, financial transparency reflects the stakeholders' facil access to the internal information of the public sector entities to evaluate their capacity to answer the expectations in terms of cost, quality, diversity, opportunity and continuity regarding the offered services.

From the view of public hospitals subordinated to the Health ministry, the undertaken research points out the low degree of financial transparency. For $71 \%$ of the hospitals analysed through the agency of the official sites, financial transparency is limited to publishing the revenue and expenditure budget. Only three hospitals out of the 66 displaying financial information on sites, approach transparency in exhaustive manner, respectively, by complete financial statements.

A small number of hospitals chose to promote financial transparency in partial manner. By one financial report, respectively the budgetary execution account $(12 \%)$, ballance sheet (8\%), patrimony outcome account (3\%). Also, there seems to be limited the initiative of hospitals to improve transparency by publishing certain complementary financial information (registers of operations generating payment bonds, monthly execution of revenue and expenditure budget, reports regarding the monthly consumption of medicines, expenses for externalized medical services, daily payments, trial ballance, tariffs of analyses and medical investigations offered) due to structure heterogenity and information reporting period.

From geographical point of biew, there are no significant differences in respect of financial transparency degree at the hospital level. From temporal point of view, the published financial information is heterogeneous both at individual and global level, fact that diminishes its comparison in time and space. The difficulty in investigating the financial transparency of hospitals is also increased by the difficulty of identifying the official sites of hospitals when lacking the public database at the level of Health Ministry, as a superior hierarchy entity.

Complementarily, the focus of the national accounting regulators upon the promotion of intrasector financial transparency, the discrepancies between the regulations approaching laconically this aspect, and also the low and divergent initiative of public hospitals to assure and develop financial transparency in a complete and integrated manner, generate confusion at the level of hospital management and disbelief at the stakeholders' level. Also, the typology of the public health insurance system from Romania, which is founded on the mandatory contributions of individuals and entities to the health insurance budget, requires a high degree of financial transparency. The limitation of the financial transparency for the public hospitals is amplified by the incomplete financial information, given the fact that the disclosure primarily takes place at the level of the individual components of the financial statements.

In this respect, we consider that a major role within the process of developing and consolidating the financial transparency within the public sector comes to the accounting regulation bodies, the professional accounting ones, the accounting profession and also, to the management of hospitals, in order to develop, integrate and promote within the regulations, a section dedicated to financial transparency, taking into account the complexity of these entities, the financing manner and the significant number of stakeholders.

In terms of the research boundaries, we consider that one of them is the lack of comparison at the level of similar hospitals from the member states of the European Union, given that there was investigated only financial information presented on the official sites by the public hospitals subordinated to the Health Ministry from Romania. Taking into consideration the fact that the organization of the health public system and its financing manners are different at the European level, the risk of non detection of certain hospitals bearing identical characteristics is high and comparison is not relevant. 
As future research directions, we propose continuing with the financial transparency investigation within decentralized hospitals at the level of of local public administration to emphasize to what extent the degree of hierarchy subordination influences the degree of financial transparency.

\section{References}

1. Ayoubi S., 2009. Le potentiel d'optimisation du système suisse de santé, available on-line at http://lavieeconomique.ch/fr/editions/200911/pdf/Ayoubi.pdf accessed on 30.03.2014

2. Ball C., 2009. What is transparency? Public Integrity, 11(4), pp. 293-308

3. Balneary and Recovery Sanatorium Mangalia, available on-line at http://www.balnear.net/ accessed on 28.03.2014

4. Balneoclimaterical Sanatorium of Children Busteni, available on-line at http://www.sanatoriulbusteni.ro/ accessed on 28.03.2014;

5. Balneary and Recovery Sanatorium Techirghiol, available on-line at http://www.sbtghiol.ro/ accessed on 28.03.2014

6. Carrin G., James C., Evans D., 2006. Atteindre la couverture universelle: Le développement $d u$ système de financement, available on-line at http://www.who.int/health_financing/documents/149-162_LAM_ch04.pdf accessed on 30.03.2014

7. Cardiovascular Recovery Hospital "Dr. Benedek Geza" Covasna, available on-line at http://www.cardiologie-covasna.ro

8. Clinical Hospital of Medical Recovery Baile Felix, available on-line at http://www.spitalfelix.ro/ accessed on 28.03.2014

9. Clinical Institute Fundeni, available on-line at http://icfundeni.ro/ accessed on 28.03.2014;

10. Clinical Hospital for Oftalmological Emergencies, available on-line at http://spitaloftalmologie.ro/ accessed on 28.03.2014

11. Clinical Institute of Urology and Renal Transplant, Cluj-Napoca, available on-line at http://www.institut-urologie.ro/spital_urologie.html accessed on 28.03.2014

12. County Emergency Clinical Hospital Cluj-Napoca, available on-line at http://www.scjucluj.ro/Pages/default.aspx accessed on 28.03.2014

13. County Emergency Clinical Hospital Craiova, available on-line at http://www.scjuc.ro/ accessed on 28.03.2014

14. County Emergency Clinical Hospital Targu Mures, available on-line at http://www.spitalmures.ro/ accessed on 28.03.2014

15. County Emergency Clinical Hospital Timisoara, available on-line at http://www.spitalulmunicipal-timisoara.ro/ accessed on 28.03.2014

16. County Emergency Hospital "Sf. Pantelimon" Focsani, available on-line at http://www.spitalvn.ro/ accessed on 28.03.2014

17. Cronical Lunatic Asylum Dumbraveni, available on-line at http://www.spdumbraveni.ro/ accessed on 28.03.2014

18. County Emergency Clinical Hospital "Sf. Spiridon", available on-line at http://www.spitalspiridon.ro/ accessed on 28.03.2014

19. Doumbuya M. L., 2008. Accessibilité des services de santé en Afrique de l'Ouest : le cas de la Guinée, available on-line at http://halshs.archives-ouvertes.fr/docs/00/22/96/96/PDF/WPDoum bouya.pdf, accessed on 30.03.2014

20. Emergency Clinical Hospital, available on-line at http://www.scub.ro/ accessed on 28.03.2014 
21. Emergency Clinical Hospital "Sf. Pantelimon", available on-line at http://urgentapantelimon.ro/ accessed on 28.03.2014

22. Emergency Clinical Hospital "Bagdasar-Arseni", available on-line at http://www.bagdasararseni.ro/ accessed on 28.03.2014

23. Emergency Clinical Hospital for Plastic Surgery, available on-line at http://www.arsuri.ro/ accessed on 28.03.2014

24. Emergency Clinical Hospital for Children "Grigore Alexandrescu", available on-line at http://www.spitaluldecopii.ro/ accessed on 28.03.2014

25. Emergency Clinical Hospital for Children "M.S. Curie", available on-line at http://www.mscurie.ro/meniu_content.php accessed on 28.03.2014

26. Emergency Clinical Hospital "Sf. Ioan", available on-line at http://www.sfib.ro/ accessed on 28.03.2014

27. Emergency Heart Institute for Cardiovascular Diseases "N. Stancioiu", available on-line at http://www.institutulinimii.ro/ accessed on 28.03.2014

28. Emergency Institute for Cardiovascular Diseases and Transplant Targu Mures, available online at http://www.cardioms.ro/ accessed on 28.03.2014

29. Explanatory Dictionary of Romanian Language, available on-line at http://dexonline.ro/

30. Government of Romania, 2013. Decision no. 524 for the modification of the Government Decision no. 144/2010 regarding the organization and functioning of the Health Ministry, published into the Official Monitor of Romania no.487 dated 02.08.2013

31. Holzner B., Holzner L., 2006, Transparency in global change - The vanguard of the open society. Pittsburgh, PA : University of Pittsburgh Press

32. Hospital "N. N. Saveanu" Vidra, available on-line at http://www.spitalvidra.ro accessed on 28.03.2014

33. Hospital of Neuromotional Recovery "Dr. Corneliu Barsan" Dezna, available on-line at http://www.spitaluldezna.ro/ accessed on 28.03.2014

34. Institute of Fonoaudiology and ORLV Functional Surgery "Prof. Dr. Dorin Hociota", available on-line at http://ifacforl.ro/index.php/pagini/22/Home accessed on 28.03.2014

35. Institute of Emergency for Cardiovascular Diseases "Prof. dr. C.C. Iliescu", available online at http://www.cardioiliescu.ro/ accessed on 28.03.2014

36. Institute for Mother and Child Care "Prof. dr. A. Rusescu", available on-line at http://iomc.ro/ accessed on 28.03.2014

37. Institute of Pneumoftiziology "Marius Nasta", available on-line at http://www.mariusnasta.ro/ accessed on 28.03.2014

38. Institute of Cardiovascular Diseases "Prof. dr. G. I. M. Georgescu", available on-line at http://www.cardioiasi.ro/ accessed on 28.03.2014

39. Institute of Cardiovascular Diseases Timisoara, available on-line at http://www.cardiologie.ro/ accessed on 28.03.2014

40. IPSASB, 2014, Hanndbook of International Public Sector Accounting Pronouncements, vol. 1,2, translation, CECCAR Printing House, Bucharest

41. KPMG, 2007, Obsrvatoire KPMG. Transparence et Associations, available on-line at http://www.cerphi.org/wp-content/uploads/2011/05/tranparence-KPMG-2007.pdfaccessed accessed on on 25.03.2014

42. Langilier A., 2003, Transparence et communication $d s$ informations financieres d'une commune:enjeux, pratiques et perspectives, available on-line at http://doc.sciencespolyon.fr/Ressources/Documents/Etudiants/Memoires/Cyberdocs/MSPCP/langilier_a/pdf/lang ilier_a.pdf accessed on 25.03.2014 
43. Lunatic and Security Measures Asylum Stei, available on-line at http://www.hpsihiatriestei.ro/ accessed on 28.03.2014

44. Lunatic and Security Measures Asylum Sapoca, available on-line at http://hsapoca.ro/ accessed on 28.03.2014

45. Lunatic Asylum Zam, available on-line at http://www.spzam.ro/ accessed on 28.03.2014

46. Lunatic and Security Measures Asylum Padureni Grajduri, available on-line at http://www.padurenimhhosp.ro/ accessed on 28.03.2014

47. Lunatic Clinical Hospital "Socola", available on-line at http://www.socolaiasi.ro/ accessed on 28.03.2014

48. Lunatic and Security Measures Asylum Jebel, available on-line at http://www.spitaljebel.ro/ accessed on 28.03.2014

49. Lunatic Asylum Gataia, available on-line at http://www.spitalgataia.ro/ accessed on 28.03.2014

50. Medical Centre for Evaluation and Recovery of Children and Youth "Cristian Serban" Buzias, available on-line at http://www.ccserban.ro/ accessed on 28.03.2014

51. National Institute of Endocrinology "C. I. Parhon, available on-line at http://www.instparhon.ro/ accessed on 28.03.2014

52. National Institute of Neurology and Neurovascular Diseases, available on-line at http://www.innbn-bucuresti.ro/ accessed on 28.03.2014

53. National Institute for Complementary and Alternative Medicine "Prof. dr. Florin Bratila", available on-line at http://www.medicinacomplementarasialternativa.ro/ accessed on 28.03.2014

54. National Institute of Geriatrics and Gerontology "Ana Aslan", available on-line at http://www.ana-aslan.ro/ accessed on 28.03.2014

55. National Institute of Contagious Diseases "Prof. dr. Matei Bals", available on-line at http://www.mateibals.ro/ accessed on 28.03.2014

56. National Institute of Recovery, Physical Medicine and Balneoclimatology, available on-line at http://www.inrmfb.ro/ accessed on 28.03.2014

57. National Institute of Diabetis, Nutrition and Metabolical Diseases "N. C. Paulescu", available on-line at http://www.paulescu.ro/ accessed on 28.03.2014

58. National Clinical Centre of Neuropsihomotorial Recovery for Children "Dr. N. Robanescu", available on-line at http://www.recuperarecopii.ro/ accessed on 28.03.2014

59. Neurosis Sanatorium Predeal, available on-line http://www.nevroze-predeal.ro/ accessed on 28.03.2014

60. Oncologic Institute "Prof. dr. Al. Trestioreanu", available on-line at http://www.iob.ro/ accessed on 28.03.2014

61. Oncological Institute "Prof. dr. I. Chiricuta" available on-line at_http://www.iocn.ro/ accessed on 28.03.2014

62. Parliament of Romaniei, 2001. Law no. 544 related to free access to the public interest information, published into the Official Monitor of Romania no.663 dated 23.10.2001, with further modifications and completions

63. Parliament of Romania, 2013. Law no. 95/2006 regarding the reform within the health domain, published into the Official Monitor of Romania no.116 dated 28.02.2013, with further modifications and completions

64. Piotrowski S. J., 2007. Governmental transparency in the path of administrative reform. Albany, NY : State University of New York Press

65. Railway Clinical Hospital Oradea, available on-line at http://www.spitalcforadea.ro/ accessed on 28.03.2014 
66. Railway General Hospital Brasov, available on-line at http://www.spcfbv.ro/stire-68 accessed on 28.03.2014

67. Railway Clinical Hospital Cluj-Napoca, available on-line at http://www.spitaluluniversitarcfcluj.ro/ accessed on 28.03.2014

68. Railway Clinical Hospital Constanta, available on-line at http://www.spitalcfconstanta.ro/ accessed on 28.03.2014

69. Railway Clinical Hospital Craiova, available on-line at http://spitalcf.oltenia.ro/pag_pac.html accessed on 28.03.2014

70. Railway General Hospital Galati, available on-line at http://www.spitalgeneralcfgalati.ro/ accessed on 28.03.2014

71. Railway General Hospital Simeria, available on-line at http://www.spitalgeneralcfsimeria.ro/ accessed on 28.03.2014

72. Railway General Hospital Pascani, available on-line at http://www.spitalulgeneralcf-pascani.ro/ accessed on 28.03.2014

73. Railway Clinical Hospital Iassy, available on-line at http://www.spitaluniversitarcfiasi.ro/cinesuntem.htm accessed on 28.03.2014

74. Railway General Hospital Drobeta-Turnu Severin, available on-line at http://www.spitalcfdrobeta.ro/a5.html accessed on 28.03.2014

75. Railway General Hospital Ploiesti, available on-line at http://www.spitalcfploiesti.ro/ accessed on 28.03.2014

76. Railway General Hospital Sibiu, available on-line at http://www.spitalcfsibiu.ro/accessed on 28.03.2014

77. Railway Clinical Hospital Timisoara, available on-line at http://www.spitalcftm.ro/ accessed on 28.03.2014

78. Recovery, Physical Medicine and Balneology Clinical Hospital Eforie Nord, available online at http://efosan.ro/ accessed on 28.03.2014

79. Recovery Hospital Borsa, available on-line at http://www.spitalrecuperare.ro/accessed on 28.03.2014

80. Regional Institute of Gastroenterology and Hepatology "Prof. dr. Octavian Fodor" ClujNapoca, available on-line at http://www.irgh.ro/ro/ accessed on 28.03.2014

81. Regional Oncological Institute Iassy, available on-line at http://iroiasi.ro/ accessed on 28.03.2014

82. Regional Institute of Oncology Timisoara, available on-line at http://iroiasi.ro/ accessed on 28.03.2014

83. Saout C., 2010. Santé publique, 22 (1), pp. 107-112, available on-line at http://fulltext.bdsp.ehesp.fr/Sfsp/SantePublique/2010/1/107_112.pdf $\quad$ accessed on 25.03.2014

84. Ştefănescu A., Țurlea E., 2013. Dissemination of financial informationa into the public sector-an approach from the view of the central public administration entities from Romania, Series Oeconomica, Alba Iulia, 15 (1), pp. 134-144, available on-line at http://www.uab.ro/oeconomica/ accessed on 25.03.2014

85. Ştefănescu A., Ţurlea E., Calu D. A., Pitulice I. C., 2013. An investigation regarding performance approaches in the romanian public sector: the case of public hospitals, 8 th International Conference on Accounting and Management Information Systems (AMIS), 12-13 iunie 2013, Bucharest

86. The Ministry of Finance, 2005. Order of the Public Finance Minister no. 1917 for the approval of Methodological regulations regarding the accounting organization and management of public entities, Accounts planning for the public institutions and the 
instructions to apply it, published into the Official Monitor of Romania no. 1.18 bis dated 29.12.2005

87. The Ministry of Finance, 2013, Order of the Public Finance Minister no 2021 to modify and complete the methodological regulations regarding the accounting organization and management of public institutions, the plan of accounts for the public entities and the instructions to apply it, approved by Order of Public Finance Minister no. 1917/2005;

88. University Emergency Hospital Bucharest, available on-line at http://www.suub.ro/ accessed on 28.03.2014 
Financial transparency into the public hospitals subordinated to the Health Ministry

\begin{tabular}{|c|c|c|c|}
\hline$\stackrel{\vec{\Xi}}{\Xi}$ & $\begin{array}{c}\text { Name of the health } \\
\text { unit/county }\end{array}$ & Site & Financial information \\
\hline$\sum^{\pi}$ & $\begin{array}{l}\text { Hospital of } \\
\text { Neuromotional Recovery } \\
\text { "Dr. Corneliu Barsan" } \\
\text { Dezna }\end{array}$ & http://www.spitaluldezna.ro/ & $\begin{array}{l}\text { - There is no financial } \\
\text { information. }\end{array}$ \\
\hline \multirow{3}{*}{ 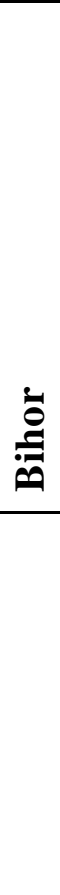 } & $\begin{array}{l}\text { Clinical Hospital of } \\
\text { Medical Recovery Baile } \\
\text { Felix }\end{array}$ & http://www.spitalfelix.ro/ & $\begin{array}{l}\text { - There is no financial } \\
\text { information. }\end{array}$ \\
\hline & $\begin{array}{l}\text { Lunatic and Security } \\
\text { Measures Asylum Stei }\end{array}$ & $\begin{array}{l}\text { http://www.hpsihiatriestei. } \\
\text { ro/ }\end{array}$ & $\begin{array}{l}\text { - Revenue and expenditure } \\
\text { budgets for the period 2008- } \\
2012 \text {. } \\
\text { - Account of budgetary } \\
\text { execution for the period 2009- } \\
2011 \text { and September-August } \\
2012 \text {. }\end{array}$ \\
\hline & $\begin{array}{l}\text { Railway Clinical } \\
\text { Hospital Oradea }\end{array}$ & $\begin{array}{l}\text { http://www.spitalcforadea. } \\
\text { ro/ }\end{array}$ & $\begin{array}{l}\text { - Revenue and expenditure } \\
\text { budgets for the period 2010- } \\
2012 \text {. } \\
\text { - Tariffs for the medical services } \\
\text { offered on request. } \\
\text { - Register of operations } \\
\text { generating payment bonds for } \\
\text { the period 2012-2014 }\end{array}$ \\
\hline \multirow[t]{2}{*}{ 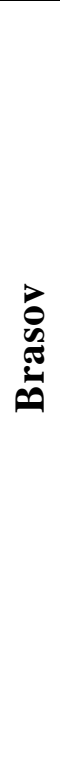 } & $\begin{array}{l}\text { Neurosis Sanatorium } \\
\text { Predeal }\end{array}$ & $\begin{array}{l}\text { http://www.nevroze- } \\
\text { predeal.ro/ }\end{array}$ & $\begin{array}{l}\text { - Monthly and annual financial } \\
\text { statements for the period 2010- } \\
2013 \text {. } \\
\text { - Monthly execution of the } \\
\text { revenue and expenditure } \\
\text { budget for the period 2011- } \\
2014 \text {. } \\
\text { - Report on the activity of } \\
\text { preventive financial control. }\end{array}$ \\
\hline & $\begin{array}{l}\text { Railway General } \\
\text { Hospital Brasov }\end{array}$ & $\begin{array}{l}\text { http://www.spcfbv.ro/stire- } \\
68\end{array}$ & $\begin{array}{l}\text { - Revenue and expenditure } \\
\text { budgets for year } 2013 \text {. } \\
\text { - Budgetary execution account } \\
\text { for } 2013 \text {. } \\
\text { - Register of operations } \\
\text { generating payment bonds for } \\
\text { the period 2012-2014. }\end{array}$ \\
\hline
\end{tabular}




\begin{tabular}{|c|c|c|c|}
\hline \multirow{11}{*}{ 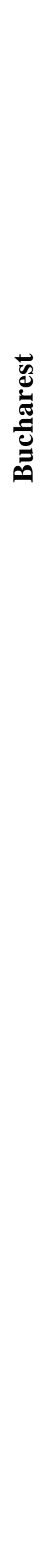 } & $\begin{array}{l}\text { Institute of } \\
\text { Fonoaudiology and } \\
\text { ORLV Functional } \\
\text { Surgery "Prof. Dr. } \\
\text { Dorin Hociota" }\end{array}$ & $\begin{array}{l}\text { http://ifacforl.ro/index.php } \\
\text { /pagini/22/Home }\end{array}$ & $\begin{array}{l}\text { - Revenue and expenditure } \\
\text { budget for year } 2012 \text {. } \\
\text { - Tariffs for medical services } \\
\text { offered within day care and } \\
\text { continuous hospitalization. }\end{array}$ \\
\hline & $\begin{array}{l}\text { National Institute of } \\
\text { Endocrinology "C. I. } \\
\text { Parhon }\end{array}$ & http://www.instparhon.ro/ & $\begin{array}{c}\text { - Revenue and expenditure } \\
\text { budget for year } 2012 .\end{array}$ \\
\hline & $\begin{array}{l}\text { National Institute of } \\
\text { Neurology and } \\
\text { Neurovascular Diseases }\end{array}$ & $\begin{array}{l}\text { http://www.innbn- } \\
\text { bucuresti.ro/ }\end{array}$ & $\begin{array}{l}\text { - Revenue and expenditure } \\
\text { budgets for period 2009-2014. } \\
\text { - Expenses for the externalized } \\
\text { medical services during 2012- } \\
2014 . \\
\text { - Tariffs applied for services } \\
\text { discounted by CASMB. }\end{array}$ \\
\hline & $\begin{array}{l}\text { National Institute for } \\
\text { Complementary and } \\
\text { Alternative Medicine } \\
\text { "Prof. dr. Florin Bratila" }\end{array}$ & $\begin{array}{l}\text { http://www.medicinacomp } \\
\text { lementarasialternativa.ro/ }\end{array}$ & $\begin{array}{l}\text { - Financial statements on the } \\
\text { 31.12.2007. }\end{array}$ \\
\hline & $\begin{array}{l}\text { National Institute of } \\
\text { Geriatrics and } \\
\text { Gerontology "Ana } \\
\text { Aslan" }\end{array}$ & http://www.ana-aslan.ro/ & $\begin{array}{l}\text { - Revenue and expenditure } \\
\text { budget for year } 2013 \text {. }\end{array}$ \\
\hline & $\begin{array}{l}\text { National Institute of } \\
\text { Contagious Diseases } \\
\text { "Prof. dr. Matei Bals" }\end{array}$ & http://www.mateibals.ro/ & $\begin{array}{l}\text { - Revenue and expenditure } \\
\text { budget for year } 2012 \text {. } \\
\text { - Tariffs of medical analyses } \\
\text { performed on demand. }\end{array}$ \\
\hline & $\begin{array}{l}\text { National Institute of } \\
\text { Recovery, Physical } \\
\text { Medicine and } \\
\text { Balneoclimatology }\end{array}$ & http://www.inrmfb.ro/ & $\begin{array}{l}\text { Revenue and expenditure } \\
\text { budget for the year } 2012\end{array}$ \\
\hline & $\begin{array}{l}\text { Oncologic Institute } \\
\text { "Prof. dr. Al. } \\
\text { Trestioreanu" }\end{array}$ & http://www.iob.ro/ & $\begin{array}{l}\text { - Revenue and expenditure } \\
\text { budgets for period 2009-2013. } \\
\text { - Consumption slips of the } \\
\text { medicines for the months } \\
\text { December 2013, January } \\
\text { 2014, February } 2014\end{array}$ \\
\hline & $\begin{array}{l}\text { Institute of Emergency } \\
\text { for Cardiovascular } \\
\text { Diseases "Prof. dr. C.C. } \\
\text { Iliescu" }\end{array}$ & http://www.cardioiliescu.ro/ & $\begin{array}{l}\text { - Revenue and expenditure } \\
\text { budget for year } 2012 \text {. }\end{array}$ \\
\hline & $\begin{array}{l}\text { Institute for Mother and } \\
\text { Child Care "Prof. dr. A. } \\
\text { Rusescu" }\end{array}$ & http://iomc.ro/ & $\begin{array}{l}\text { - Tariffs of medical } \\
\text { examinations and analyses not } \\
\text { discounted. }\end{array}$ \\
\hline & $\begin{array}{l}\text { Institute of } \\
\text { Pneumoftiziology } \\
\text { "Marius Nasta" }\end{array}$ & http://www.mariusnasta.ro/ & - Non operational site. \\
\hline
\end{tabular}




\begin{tabular}{|c|c|c|c|}
\hline & $\begin{array}{l}\text { National Institute of } \\
\text { Diabetis, Nutrition and } \\
\text { Metabolical Diseases "N. } \\
\text { C. Paulescu" }\end{array}$ & http://www.paulescu.ro/ & $\begin{array}{l}\text { - Revenue and expenditure } \\
\text { budget for year } 2009 .\end{array}$ \\
\hline & $\begin{array}{l}\text { Clinical Institute } \\
\text { Fundeni }\end{array}$ & http://icfundeni.ro/ & $\begin{array}{l}\text { - There is not displayed } \\
\text { financial information. }\end{array}$ \\
\hline & $\begin{array}{l}\text { Emergency Clinical } \\
\text { Hospital }\end{array}$ & http://www.scub.ro/ & $\begin{array}{l}\text { - Revenue and expenditure } \\
\text { budget for year } 2009 \text {. }\end{array}$ \\
\hline & $\begin{array}{l}\text { Emergency Clinical } \\
\text { Hospital "Sf. } \\
\text { Pantelimon" } \\
\end{array}$ & http://urgentapantelimon.ro/ & $\begin{array}{l}\text { - There is not displayed } \\
\text { financial information. }\end{array}$ \\
\hline & $\begin{array}{l}\text { Emergency Clinical } \\
\text { Hospital "Bagdasar- } \\
\text { Arseni" }\end{array}$ & $\begin{array}{l}\text { http://www.bagdasar- } \\
\text { arseni.ro/ }\end{array}$ & $\begin{array}{l}\text { Revenue and expenditure } \\
\text { budgets for period 2010-2012. }\end{array}$ \\
\hline & $\begin{array}{l}\text { University Emergency } \\
\text { Hospital Bucharest }\end{array}$ & http://www.suub.ro/ & $\begin{array}{l}\text { - Revenue and expenditure } \\
\text { budget for year } 2012 \text {. } \\
\text { - Tariffs concerning the discount } \\
\text { of hospitalization expenses } \\
\text { for non-insurred patients }\end{array}$ \\
\hline & $\begin{array}{l}\text { Emergency Clinical } \\
\text { Hospital for Plastic } \\
\text { Surgery }\end{array}$ & http://www.arsuri.ro/ & $\begin{array}{l}\text { - There is not displayed } \\
\text { financial information. }\end{array}$ \\
\hline & $\begin{array}{l}\text { Emergency Clinical } \\
\text { Hospital for Children } \\
\text { "Grigore Alexandrescu" }\end{array}$ & $\begin{array}{l}\text { http://www.spitaluldecopii } \\
\text {.ro/ }\end{array}$ & $\begin{array}{l}\text { Revenue and expenditure } \\
\text { budget for years } 2010,2011 .\end{array}$ \\
\hline & $\begin{array}{l}\text { Emergency Clinical } \\
\text { Hospital for Children } \\
\text { "M.S. Curie" }\end{array}$ & $\begin{array}{l}\text { http://www.mscurie.ro/me } \\
\text { niu_content.php }\end{array}$ & $\begin{array}{l}\text { - Revenue and expenditure } \\
\text { budget for year } 2009 \text {. } \\
\text { - Expenses for the externalized } \\
\text { medical and non-medical } \\
\text { services. }\end{array}$ \\
\hline & $\begin{array}{l}\text { Emergency Clinical } \\
\text { Hospital "Sf. Ioan" }\end{array}$ & http://www.sfib.ro/ & $\begin{array}{l}\text { - There is not displayed } \\
\text { financial information. }\end{array}$ \\
\hline & $\begin{array}{l}\text { Clinical Hospital for } \\
\text { Oftalmological } \\
\text { Emergencies } \\
\end{array}$ & http://spitaloftalmologie.ro/ & $\begin{array}{l}\text { Revenue and expenditure } \\
\text { budget for year } 2009 \text {. }\end{array}$ \\
\hline & $\begin{array}{l}\text { National Clinical Centre } \\
\text { of Neuropsihomotorial } \\
\text { Recovery for Children } \\
\text { "Dr. N. Robanescu" }\end{array}$ & $\begin{array}{l}\text { http://www.recuperarecopii. } \\
\underline{\text { ro/ }}\end{array}$ & $\begin{array}{l}\text { Revenue and expenditure } \\
\text { budget for year } 2009 \text {. }\end{array}$ \\
\hline 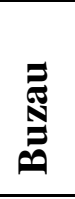 & $\begin{array}{l}\text { Lunatic and Security } \\
\text { Measures Asylum } \\
\text { Sapoca }\end{array}$ & http://hsapoca.ro/ & $\begin{array}{l}\text { - Revenue and expenditure } \\
\text { budget for year } 2012 \text {. } \\
\text { - Daily payments for the period } \\
2012-2014 \text {. }\end{array}$ \\
\hline
\end{tabular}




\begin{tabular}{|c|c|c|c|}
\hline & $\begin{array}{l}\text { Emergency Heart } \\
\text { Institute for } \\
\text { Cardiovascular Diseases } \\
\text { "N. Stancioiu" }\end{array}$ & $\begin{array}{l}\text { http://www.institutulinimii } \\
\text {.ro/ }\end{array}$ & $\begin{array}{l}\text { - Revenue and expenditure } \\
\text { budgets for period 2006-2013. } \\
\text { - Expenses for externalized } \\
\text { non-medical services. } \\
\text { - Tariffs for interclinical } \\
\text { examinations and } \\
\text { examinations on demand. }\end{array}$ \\
\hline$\Xi$ & $\begin{array}{l}\text { Oncological Institute } \\
\text { "Prof. dr. I. Chiricuta" }\end{array}$ & http://www.iocn.ro/ & 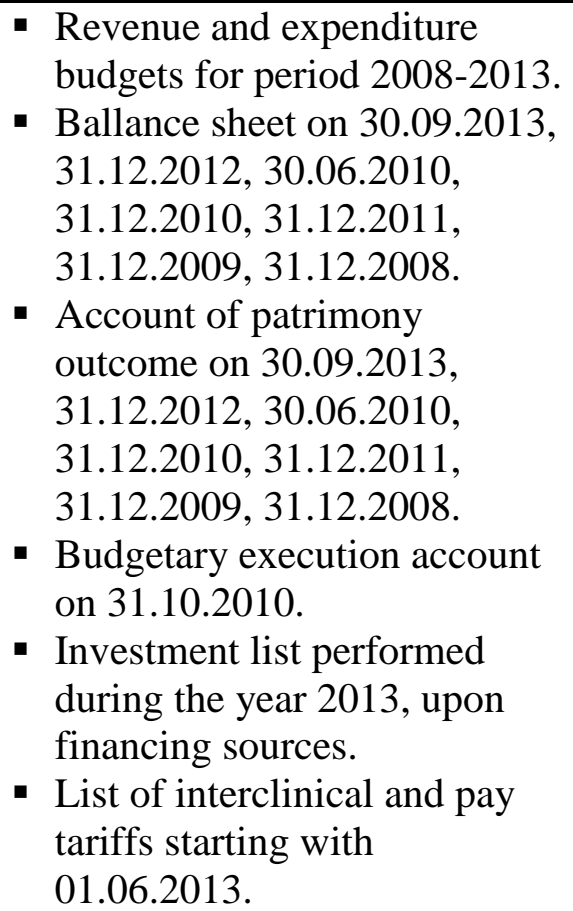 \\
\hline & $\begin{array}{l}\text { Clinical Institute of } \\
\text { Urology and Renal } \\
\text { Transplant }\end{array}$ & $\begin{array}{l}\text { http://www.institut- } \\
\text { urologie.ro/spital_urologie } \\
. \text { html }\end{array}$ & $\begin{array}{l}\text { - There is not displayed } \\
\text { financial information. }\end{array}$ \\
\hline & $\begin{array}{l}\text { County Emergency } \\
\text { Clinical Hospital Cluj- } \\
\text { Napoca }\end{array}$ & $\begin{array}{l}\text { http://www.scju- } \\
\text { cluj.ro/Pages/default.aspx }\end{array}$ & $\begin{array}{l}\text { - Outstanding payments on } \\
\text { 31.08.2013 and related } \\
\text { annotation. }\end{array}$ \\
\hline & $\begin{array}{l}\text { Regional Institute of } \\
\text { Gastroenterology and } \\
\text { Hepatology "Prof. dr. } \\
\text { Octavian Fodor" Cluj- } \\
\text { Napoca }\end{array}$ & http://www.irgh.ro/ro/ & $\begin{array}{c}\text { - Revenue and expenditure } \\
\text { budget for year } 2012 .\end{array}$ \\
\hline & $\begin{array}{l}\text { Railway Clinical } \\
\text { Hospital Cluj-Napoca }\end{array}$ & $\begin{array}{l}\text { http://www.spitalulunivers } \\
\text { itarcfcluj.ro/ }\end{array}$ & $\begin{array}{l}\text { - Revenue and expenditure } \\
\text { budget for year } 2005 \\
\text { - Register of operations } \\
\text { generating payment bonds for } \\
\text { the years } 2012,2013 \text {. } \\
\text { - List of tariffs for analyses. }\end{array}$ \\
\hline
\end{tabular}




\begin{tabular}{|c|c|c|c|}
\hline \multirow{3}{*}{ 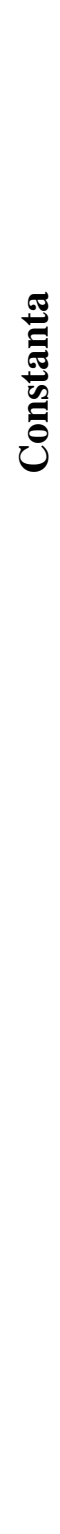 } & $\begin{array}{l}\text { Balneary and Recovery } \\
\text { Sanatorium Mangalia }\end{array}$ & http://www.balnear.net/ & $\begin{array}{l}\text { - Revenue and expenditure } \\
\text { budget for year } 2013 \text {. } \\
\text { - Tariffs for reception of } \\
\text { Romanian insurred patients - } \\
2014 \text {. } \\
\text { - List of prices for medical } \\
\text { analyses. }\end{array}$ \\
\hline & $\begin{array}{l}\text { Recovery, Physical } \\
\text { Medicine and } \\
\text { Balneology Clinical } \\
\text { Hospital Eforie Nord }\end{array}$ & http://efosan.ro/ & $\begin{array}{l}\text { - Revenue and expenditure } \\
\text { budget for year } 2013 \text {. } \\
\text { - Ballance sheet on } 30.09 .2013 \text {. } \\
31.12 .2012 \\
\text { - Budgetary execution account } \\
\text { on } 30.09 .2013,31.07 .2013 \text {, } \\
\text { 31.12.2012 } \\
\text { - Tariffs for proceedings and } \\
\text { investigations }\end{array}$ \\
\hline & $\begin{array}{l}\text { Balneary and Recovery } \\
\text { Sanatorium Techirghiol }\end{array}$ & http://www.sbtghiol.ro/ & $\begin{array}{l}\text { - } \text { Ballance sheet related to the } \\
\text { periods: } 30.06 .2013, \\
\text { 31.12.2013, 31.12.2012, } \\
\text { 31.12.2011, 31.12.2010, } \\
\text { 31.12.2009, 31.12.2008, } \\
\text { 31.12.2007, 31.12.2006 } \\
\text { - Patrimony outcome account } \\
\text { related to the periods: } \\
\text { 30.06.2013, 31.12.2013, } \\
\text { 31.12.2012, 31.12.2011, } \\
\text { 31.12.2010, 31.12.2009, } \\
\text { Budgetary execution account } \\
\text { related to the periods: } \\
\text { 30.06.2013, 31.12.2013, } \\
\text { 31.12.2012, 31.12.2011, } \\
\text { 31.12.2010, 31.12.2009 }\end{array}$ \\
\hline
\end{tabular}




\begin{tabular}{|c|c|c|c|}
\hline & & & $\begin{array}{l}\text { - Treasury flow statement on } \\
\text { 31.12.2009. } \\
\text { - Statement of modification } \\
\text { within the structure of net } \\
\text { assets / own capitals on } \\
\text { 31.12.2009. } \\
\text { - Summary of financing for } \\
\text { programmes on } 31.12 .2009 \text {. } \\
\text { - Budget on programmes } \\
\text { updated for the year } 2009 \text {. } \\
\text { - Outstanding treasury } \\
\text { payments on } 31.12 .2009 . \\
\text { - Situation of depreciable assets } \\
\text { on } 31.12 .2009 \text {. } \\
\text { - Situation of assets and } \\
\text { financial debts of public } \\
\text { entities belonging to the } \\
\text { central administration on } \\
\text { 31.12.2009. } \\
\text { - Budgetary execution for the } \\
\text { months January } 2010-\text { April } \\
\text { 2013, September 2013. } \\
\text { - Revenue and expenditure } \\
\text { budgets for period 2009-2013, } \\
\text { January 2014. } \\
\text { - Report regarding the monthly } \\
\text { consumption of medicines for } \\
\text { the period August-December } \\
\text { 2013, January-February } 2014\end{array}$ \\
\hline & $\begin{array}{l}\text { Railway Clinical } \\
\text { Hospital Constanta }\end{array}$ & $\begin{array}{l}\underline{\text { http://www.spitalcfconstan }} \\
\underline{\text { ta.ro/ }}\end{array}$ & $\begin{array}{l}\text { - Register of operations } \\
\text { generating payment bonds for } \\
\text { the years 2012, } 2013 \text {. } \\
\text { - Tariffs for medical } \\
\text { examinations and services. }\end{array}$ \\
\hline 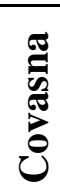 & $\begin{array}{l}\text { Cardiovascular Recovery } \\
\text { Hospital "Dr. Benedek } \\
\text { Geza" Covasna }\end{array}$ & $\begin{array}{l}\text { http://www.cardiologie- } \\
\text { covasna.ro/ }\end{array}$ & $\begin{array}{l}\text { Tariffs for paraclinical } \\
\text { investigations for the year } \\
2012 \text {. }\end{array}$ \\
\hline \multirow[t]{3}{*}{$\ddot{\overline{8}}$} & $\begin{array}{l}\text { County Emergency } \\
\text { Clinical Hospital Craiova }\end{array}$ & http://www.scjuc.ro/ & $\begin{array}{l}\text { - Revenue and expenditure } \\
\text { budget for year } 2014 \text {. } \\
\text { - Summary on the tariffs for } \\
\text { medical services calculated at } \\
\text { the entity level valid from the } \\
\text { date of } 01.06 .2013 \text {. }\end{array}$ \\
\hline & $\begin{array}{l}\text { Lunatic Asylum Poiana } \\
\text { Mare }\end{array}$ & No site & Not applicable \\
\hline & $\begin{array}{l}\text { Railway Clinical } \\
\text { Hospital Craiova }\end{array}$ & $\begin{array}{l}\text { http://spitalcf.oltenia.ro/pa } \\
\text { g_pac.html }\end{array}$ & $\begin{array}{l}\text { - Balance sheet on } 30.06 .2011 . \\
\text { - Revenue and expenditure }\end{array}$ \\
\hline
\end{tabular}




\begin{tabular}{|c|c|c|c|}
\hline & & & $\begin{array}{l}\text { budget for year } 2011 \text {. } \\
\text { Tariffs for medical services } \\
\text { valid starting on the date of } \\
01.10 .2010\end{array}$ \\
\hline ש़ & $\begin{array}{l}\text { Railway General } \\
\text { Hospital Galati }\end{array}$ & $\begin{array}{l}\text { http://www.spitalgeneralcf } \\
\text { galati.ro/ }\end{array}$ & $\begin{array}{l}\text { Register of operations } \\
\text { generating payment bonds for } \\
\text { the years } 2012,2013,2014 \text {. } \\
\text { - Tariffs for hospitalization } \\
\text { services valid starting on the } \\
\text { date of } 01.02 .2012 \text {. } \\
\text { - Tariffs for medical services } \\
\text { offered on demand valid } \\
\text { starting on the date of } \\
\text { 01.01.2011. }\end{array}$ \\
\hline & Lunatic Asylum Zam & http://www.spzam.ro/ & $\begin{array}{l}\text { - Revenue and expenditure } \\
\text { budget for year } 2009 \text {. } \\
\text { - Monthly consumption of } \\
\text { medicines for the year } 2013 \text {. }\end{array}$ \\
\hline 莺 & $\begin{array}{l}\text { Railway General } \\
\text { Hospital Simeria }\end{array}$ & $\begin{array}{l}\text { http://www.spitalgeneralcf } \\
\text { simeria.ro/ }\end{array}$ & $\begin{array}{l}\text { - Register of operations } \\
\text { generating payment bonds for } \\
\text { the years 2012, } 2013 \text {. } \\
\text { - Reporting regarding the } \\
\text { consumption on wards for } \\
\text { January } 2014 \text {. } \\
\text { - Tariffs for clinical medical } \\
\text { services and paraclinical } \\
\text { investigations performed on } \\
\text { demand. }\end{array}$ \\
\hline \multirow{3}{*}{ 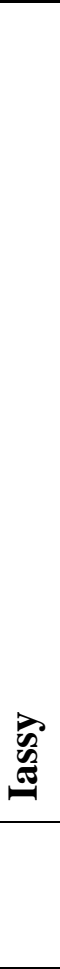 } & $\begin{array}{l}\text { Regional Oncological } \\
\text { Institute Iassy }\end{array}$ & http://iroiasi.ro/ & $\begin{array}{l}\text { - Ballance sheet for suppliers on } \\
\text { 31.12.2013. } \\
\text { - Budgetary execution on } \\
28.02 .2014 \text {. } \\
\text { - Revenue and expenditure } \\
\text { budget for year } 2013 \text {. } \\
\text { - Synthetical trial ballance on } \\
\text { 31.01.2014, 28.02.2014. } \\
\text { - Budgetary execution account } \\
\text { on } 31.12 .2013 \text {. }\end{array}$ \\
\hline & $\begin{array}{l}\text { Institute of } \\
\text { Cardiovascular Diseases } \\
\text { "Prof. dr. G. I. M. } \\
\text { Georgescu" }\end{array}$ & http://www.cardioiasi.ro/ & $\begin{array}{l}\text { - Ballance sheet on } 30.06 .2010 \text {. } \\
\text { - Patrimony outcome account on } \\
30.06 .2010 \text {. } \\
\text { - Synthetical trial ballance on } \\
30.06 .2010 \text {. } \\
\text { - Revenue and expenditure } \\
\text { budget for year } 2009 \text {. }\end{array}$ \\
\hline & $\begin{array}{l}\text { County Emergency } \\
\text { Clinical Hospital "Sf. } \\
\text { Spiridon" }\end{array}$ & http://www.spitalspiridon.ro/ & $\begin{array}{l}\text { - Revenue and expenditure } \\
\text { budget for year } 2012 \text {. } \\
\text { - Situation of medicine }\end{array}$ \\
\hline
\end{tabular}




\begin{tabular}{|c|c|c|c|}
\hline & & & $\begin{array}{l}\text { consumption for the years } \\
2013,2014 \text {. }\end{array}$ \\
\hline & $\begin{array}{l}\text { Lunatic and Security } \\
\text { Measures Asylum } \\
\text { Padureni Grajduri }\end{array}$ & $\begin{array}{l}\text { http://www.padurenimhho } \\
\underline{\text { sp.ro/ }}\end{array}$ & $\begin{array}{l}\text { - Revenue and expenditure } \\
\text { budgets for years } 2009,2012 \text {. } \\
\text { - Expenses for medical and non- } \\
\text { medical services for the period } \\
2008,2009 \text {. }\end{array}$ \\
\hline & $\begin{array}{l}\text { Lunatic Clinical Hospital } \\
\text { "Socola" }\end{array}$ & http://www.socolaiasi.ro/ & $\begin{array}{l}\text { - The sections intended for the } \\
\text { financial reporting and the } \\
\text { tariffs for the medical services } \\
\text { are not active. }\end{array}$ \\
\hline & $\begin{array}{l}\text { Railway General } \\
\text { Hospital Pascani }\end{array}$ & $\begin{array}{l}\text { http://www.spitalulgeneral } \\
\text { cf-pascani.ro/ }\end{array}$ & - Non-operational site. \\
\hline & $\begin{array}{l}\text { Railway Clinical } \\
\text { Hospital Iassy }\end{array}$ & $\begin{array}{l}\underline{\mathrm{http}: / / \mathrm{www} \cdot \text { spitaluniversit }} \\
\underline{\text { arcfiasi.ro/cinesuntem.htm }}\end{array}$ & $\begin{array}{l}\text { - Register of operations } \\
\text { generating payment bonds for } \\
\text { the year } 2012 \text {. } \\
\text { - Tariffs of medical services. }\end{array}$ \\
\hline 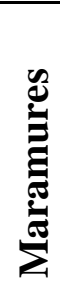 & Recovery Hospital Borsa & $\begin{array}{l}\text { http://www.spitalrecuperar } \\
\text { e.ro/ }\end{array}$ & $\begin{array}{l}\text { - Revenue and expenditure } \\
\text { budgets for years 2011, } 2012 \text {. } \\
\text { - Budgetary execution account } \\
\text { on } 30.09 .2013 \text {. } \\
\text { - Tariffs of hospitalization and } \\
\text { ambulatory services. }\end{array}$ \\
\hline : & $\begin{array}{l}\text { Railway General } \\
\text { Hospital Drobeta-Turnu } \\
\text { Severin }\end{array}$ & $\begin{array}{l}\text { http://www.spitalcfdrobeta } \\
\text {.ro/a5.html }\end{array}$ & $\begin{array}{l}\text { Register of operations } \\
\text { generating payment bonds for } \\
\text { the years 2012, } 2013 \text {. } \\
\text { - Tariff of solved case (DRG) } \\
\text { for internal and surgical } \\
\text { wards. }\end{array}$ \\
\hline \multirow[t]{2}{*}{ 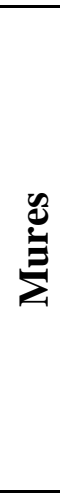 } & $\begin{array}{l}\text { County Emergency } \\
\text { Clinical Hospital Targu } \\
\text { Mures }\end{array}$ & http://www.spitalmures.ro/ & $\begin{array}{l}\text { - Revenue and expenditure } \\
\text { budgets for years } 2009,2010 \text {, } \\
2011 \\
\text { - Tariffs per hospitalization day } \\
\text { on ward related to the month } \\
\text { of January } 2013 \text {. }\end{array}$ \\
\hline & $\begin{array}{l}\text { Emergency Institute for } \\
\text { Cardiovascular Diseases } \\
\text { and Transplant Targu } \\
\text { Mures }\end{array}$ & http://www.cardioms.ro/ & - Non-operational site. \\
\hline 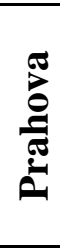 & $\begin{array}{l}\text { Balneoclimaterical } \\
\text { Sanatorium of Children } \\
\text { Busteni }\end{array}$ & $\begin{array}{l}\text { http://www.sanatoriulbuste } \\
\underline{\text { ni.ro/ }}\end{array}$ & $\begin{array}{l}\text { - Revenue and expenditure } \\
\text { budgets for years } 2013,2014 \text {. } \\
\text { - Monthly consumption of } \\
\text { medicines related to the period } \\
\text { May } 2013 \text { - January } 2014 \text {. }\end{array}$ \\
\hline
\end{tabular}




\begin{tabular}{|c|c|c|c|}
\hline & $\begin{array}{l}\text { Railway General } \\
\text { Hospital Ploiesti }\end{array}$ & $\begin{array}{l}\text { http://www.spitalcfploiesti } \\
\text {.ro/ }\end{array}$ & $\begin{array}{l}\text { - Revenue and expenditure } \\
\text { budgets for years } 2011,2012 \text {. } \\
\text { - Total consumption of } \\
\text { medicines from the unique } \\
\text { national fund of social health } \\
\text { insurance. } \\
\text { - Register of operations } \\
\text { generating payment bonds for } \\
\text { the year } 2012 \text {. }\end{array}$ \\
\hline 光 & $\begin{array}{l}\text { Railway General } \\
\text { Hospital Sibiu }\end{array}$ & http://www.spitalcfsibiu.ro/ & $\begin{array}{l}\text { Tariffs for services offered } \\
\text { within speciality ambulatory. }\end{array}$ \\
\hline \multirow{7}{*}{$\stackrel{\mathscr{n}}{\mathscr{B}}$} & $\begin{array}{l}\text { Institute of } \\
\text { Cardiovascular Diseases } \\
\text { Timisoara }\end{array}$ & http://www.cardiologie.ro/ & $\begin{array}{l}\text { - Revenue and expenditure } \\
\text { budget for years 2009, } 2010 \text {. } \\
\text { - Expenses for externalized } \\
\text { medical and non-medical } \\
\text { services. }\end{array}$ \\
\hline & $\begin{array}{l}\text { County Emergency } \\
\text { Clinical Hospital } \\
\text { Timisoara }\end{array}$ & $\begin{array}{l}\text { http://www.spitalul- } \\
\text { municipal-timisoara.ro/ }\end{array}$ & - Tariffs for examinations. \\
\hline & $\begin{array}{l}\text { Medical Centre for } \\
\text { Evaluation and Recovery } \\
\text { of Children and Youth } \\
\text { "Cristian Serban" Buzias }\end{array}$ & http://www.ccserban.ro/ & $\begin{array}{l}\text { - Revenue and expenditure } \\
\text { budgets for years } 2010 \text {, } \\
2012 \text {. } \\
\text { - Ballance sheet summarized on } \\
\text { 31.12.2009 of the foundation } \\
\text { which the hospital is } \\
\text { associated with. }\end{array}$ \\
\hline & Lunatic Asylum Gataia & http://www.spitalgataia.ro/ & $\begin{array}{l}\text { - Revenue and expenditure } \\
\text { budgets for years } 2009,2010 \text {, } \\
2011,2012 \text {. }\end{array}$ \\
\hline & $\begin{array}{l}\text { Lunatic and Security } \\
\text { Measures Asylum Jebel }\end{array}$ & http://www.spitaljebel.ro/ & $\begin{array}{l}\text { - Revenue and expenditure } \\
\text { budgets for years } 2009,2012 \text {, } \\
2013 .\end{array}$ \\
\hline & $\begin{array}{l}\text { Regional Institute of } \\
\text { Oncology Timisoara }\end{array}$ & http://iroiasi.ro/ & $\begin{array}{l}\text { - Revenue and expenditure } \\
\text { budget for year } 2013 . \\
\text { - Synthetical trial ballance on } \\
31.01 .2014 \text { and } 28.02 .2014 . \\
\text { - Budgetary execution related to } \\
\text { January 2014, February } \\
2014 \text {. } \\
\text { - Ballance sheet for suppliers on } \\
31.12 .2013 \text { and } 31.01 .2014 . \\
\text { - Budget execution account - } \\
\text { expenses on } 31.12 .2103\end{array}$ \\
\hline & $\begin{array}{l}\text { Railway Clinical } \\
\text { Hospital Timisoara }\end{array}$ & http://www.spitalcftm.ro/ & $\begin{array}{l}\text { - Revenue and expenditure } \\
\text { budgets for years , 2014, }\end{array}$ \\
\hline
\end{tabular}




\begin{tabular}{|c|c|c|c|}
\hline & & & $\begin{array}{l}\text { 2013, } 2012 . \\
\text { - Tariffs for examinations, } \\
\text { analyses. } \\
\text { - Register of operations } \\
\text { generating payment bonds } \\
\quad \text { for the year } 2013 .\end{array}$ \\
\hline \multirow{3}{*}{ 胥 } & $\begin{array}{l}\text { County Emergency } \\
\text { Hospital "Sf. } \\
\text { Pantelimon" Focsani }\end{array}$ & http://www.spitalvn.ro/ & $\begin{array}{l}\text { - Revenue and expenditure } \\
\text { budget for year } 2009 \text {. } \\
\text { - Revenues and expenses per } \\
\text { wards related to year } 2009 \text {. } \\
\text { - Budgetary execution account } \\
\text { for } 2005 \text {. } \\
\text { - Value of expenses per } \\
\text { hospitalization day and per } \\
\text { patient for } 2005 .\end{array}$ \\
\hline & $\begin{array}{l}\text { Cronical Lunatic Asylum } \\
\text { Dumbraveni }\end{array}$ & $\begin{array}{l}\text { http://www.spdumbraveni. } \\
\text { ro/ }\end{array}$ & $\begin{array}{l}\text { - Revenues and expenses per } \\
\text { wards related to year } 2009 \text {. } \\
\text { - Monthly execution of expenses } \\
\text { for the period January 2012- } \\
\text { April } 2012 \text {. } \\
\text { - Statement of payment bonds of } \\
\text { hospital on 31.12.2011, } \\
\text { respectively 31.04. 2012. }\end{array}$ \\
\hline & $\begin{array}{l}\text { Hospital "N.N. Saveanu" } \\
\text { Vidra }\end{array}$ & http://www.spitalvidra.ro/ & $\begin{array}{r}\text { Revenue and expenditure } \\
\text { budget for the year } 2009 .\end{array}$ \\
\hline
\end{tabular}

Source: Personal design 